\title{
Polyp bailout in Pocillopora damicornis following thermal
}

\section{stress [version 1; peer review: 1 approved, 1 approved with}

\section{reservations]}

\author{
Alexander J Fordyce (D1), Emma F Camp², Tracy D Ainsworth1 \\ ${ }^{1}$ ARC Centre of Excellence for Coral Reef Studies, James Cook University, Queensland, Australia \\ ${ }^{2}$ Climate Change Cluster, University of Technology Sydney, New South Wales, Australia
}

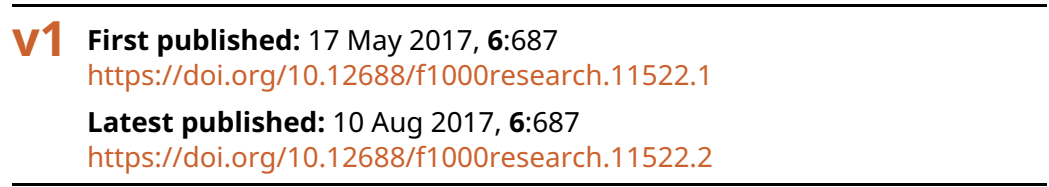

\section{Abstract}

Polyp bailout is an established but understudied coral stress response that involves the detachment of individual polyps from the colonial form as means of escaping unfavourable conditions. This may influence both the mortality and asexual recruitment of coral genotypes across a range of species. It was first described by Goreau \& Goreau (1959) and has been observed in response to numerous stressors including high salinity and low $\mathrm{pH}$. However, polyp bailout has not previously been described in association with thermal stress and the coral bleaching response, which is becoming increasingly common around the world. We present the first qualitative observation of polyp bailout following thermal stress in a mesocosm experiment. Detached polyps show similar characteristics to those described in previous studies, including the retention of endosymbiotic zooxanthellae and the ability to disperse across short distances. As the frequency of thermal stress increases globally, we suggest further detailed research into the prevalence of this response in situ and its implications for the survival of individual corals, as well as the potential for migration into cooler micro-habitats within the coral reef environment.

Keywords

polyp bailout, thermal stress, coral bleaching, Pocillopora damicornis

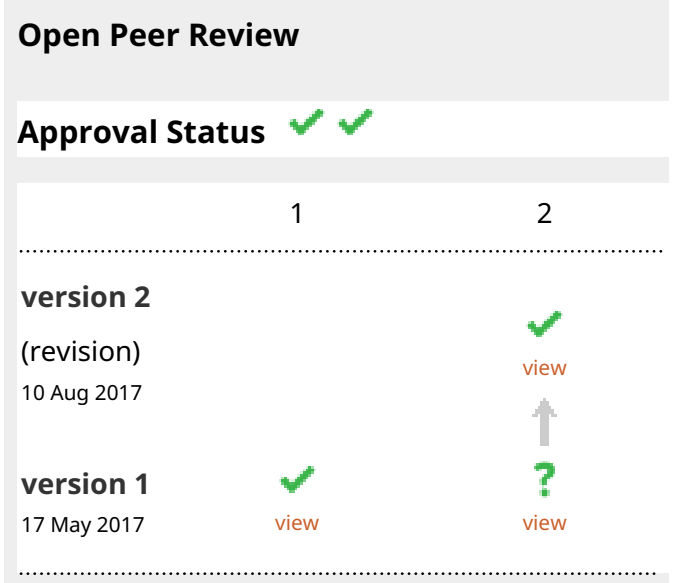

1. Sylvain Agostini, University of Tsukuba, Shizuoka, Japan

2. Dan Tchernov, University of Haifa, Haifa,

Israel

Hagit Kvitt, University of Haifa, Haifa, Israel

Any reports and responses or comments on the article can be found at the end of the article. 
Corresponding author: Alexander J Fordyce (af1721@my.bristol.ac.uk)

Competing interests: No competing interests were disclosed.

Grant information: The author(s) declared that no grants were involved in supporting this work.

Copyright: ( 2017 Fordyce AJ et al. This is an open access article distributed under the terms of the Creative Commons Attribution License, which permits unrestricted use, distribution, and reproduction in any medium, provided the original work is properly cited. Data associated with the article are available under the terms of the Creative Commons Zero "No rights reserved" data waiver (CC0 1.0 Public domain dedication).

How to cite this article: Fordyce AJ, Camp EF and Ainsworth TD. Polyp bailout in Pocillopora damicornis following thermal stress [version 1; peer review: 1 approved, 1 approved with reservations] F1000Research 2017, 6:687

https://doi.org/10.12688/f1000research.11522.1

First published: 17 May 2017, 6:687 https://doi.org/10.12688/f1000research.11522.1 


\section{Introduction}

Coral reefs around the world are facing increasingly frequent acute thermal stress events (Ainsworth et al., 2016; Hughes et al., 2017). As such there has been a corresponding increase in research into how corals respond to high temperatures, how these responses vary within individuals and communities, and how variation influences the resilience, recovery and structure of coral communities. Understanding this variation helps predict patterns of bleaching-induced mortality and reef-wide degradation. As the possibility of frequent, severe bleaching events increases (van Hooidonk et al., 2016), it is important to understand the drivers of variability in order to improve management and target restoration efforts. Polyp bailout is a possible source of variation that may influence the survival of individual genotypes and recruitment at local scales.

Polyp bailout has been observed in at least six species of scleractinian coral (Serrano et al., 2017) and involves the withdrawal of individual polyps from the coenosarc followed by their detachment from the skeleton (Sammarco, 1982). The detachment of individual polyps from a parent coral colony has previously been recorded in response to poor water quality (Sammarco, 1982; Serrano et al., 2017), large changes in $\mathrm{pH}$ (Kvitt et al., 2015), changes in salinity (Shapiro et al., 2016) and following competition from macroalgae (Sin et al., 2012). As polyps often retain their endosymbiotic dinoflagellates (zooxanthellae) and are able to re-settle, polyp bailout is thought to be a generalised escape response from detrimental conditions (Kvitt et al., 2015; Sammarco, 1982). It may therefore constitute rapid migration away from local sources of mortality.

Despite increasing temperatures being arguably the most significant threat to coral reefs (Hughes et al., 2017), this response has yet to be described during thermal stress. Here we present the first qualitative observation of polyp bailout following thermal stress in Pocillopora damicornis during an ex situ mesocosm study.

\section{Methods}

Fragments of $P$. damicornis were collected from the Heron Island reef flat in January 2017, from a maximum depth of two metres. They were housed in four 500 litre aquaria as part of an outdoors, semi-closed system supplied by a continuous flow of unfiltered seawater from the reef flat. During the week preceding simulated thermal stress, all fragments were acclimated to the aquaria and subjected to ambient conditions ( $c a .7 .980-8.020 \mathrm{pH}$; conductivity of $53-54 \mu \mathrm{S} / \mathrm{m}$; temperature of $26-30^{\circ} \mathrm{C}$; and PAR of $0-3875 \mathrm{~K})$. Following this, temperature was gradually increased in two mesocosms on top of natural variation for six days up to a peak daytime temperature of $34^{\circ} \mathrm{C}$ to simulate a severe bleaching event (as previously reported by Ainsworth et al., 2016). Two control mesocosms continued to be exposed to ambient conditions, differing from treatments in temperature only. Fragments were monitored throughout the day and when polyps were observed to bail out, they were collected using a wide-ended pipette and examined under an Olympus SZX16 stereomicroscope.

\section{Results}

On the fifth day of the simulated bleaching event, polyps were observed to begin bailing out at approximately 09:30 (Figure 1; Dataset 1, Fordyce et al., 2017). At this time, peak daytime temperature was $33^{\circ} \mathrm{C}$, which is the equivalent of 13 degree heating days, a measure of accumulated heat stress used in the prediction of mass bleaching events. By the end of day six, at peak temperature of $34^{\circ} \mathrm{C}$, reflecting 18 degree heating days, all polyps had detached (Dataset 1, Fordyce et al., 2017). At the end of the bailout period, polyps began to detach in sheets rather than as individuals. This suggests that thermal stress was too severe to allow successful withdrawal of all polyps from the coenosarc. In contrast, fragments in the control mesocosms showed no signs of bleaching or polyp bailout (Supplementary Material 1).

Bailed polyps were slightly negatively buoyant, sinking slowly, but could easily be re-suspended with mild disturbance. The detached, individual polyps retained their zooxanthellae and many were observed to extend coiled mesenterial filaments (as described in Richmond, 1985; Figure 2). Clusters of detached polyps were also observed, however these lacked calcified tissue and so did

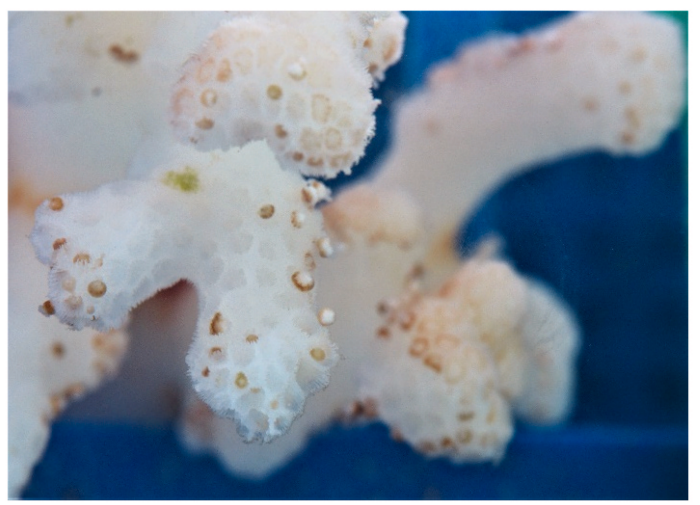

Figure 1. Photographs of polyps dropping off the skeleton of Pocillopora damicornis. Macrophotograph of polyps, having withdrawn from the connective coenosarc, dropping off the skeleton of the fragments of Pocillopora damicornis. Photograph taken with an Olympus Stylus Tough TG-4.

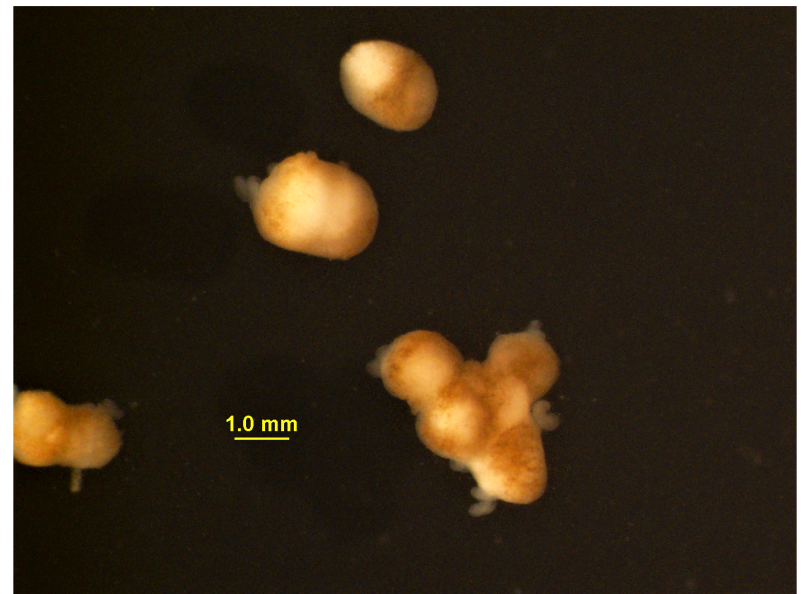

Figure 2. Single polyps and clusters of polyps with zooxanthellae and extended filaments. Micrograph of single polyps and clusters of polyps placed in a glass petri dish, taken using an Olympus SZX16 stereomicroscope with a computer-linked $2.0 x$ objective lens. Total magnification is 17.0x. Small brown dots in the polyp tissue are endosymbiotic zooxanthellae. Coiled filaments are adhesive mesenterial filaments, presumed to aid in rapid settlement. 
not resemble the larval clusters described by Richmond (1985) (Figure 2).

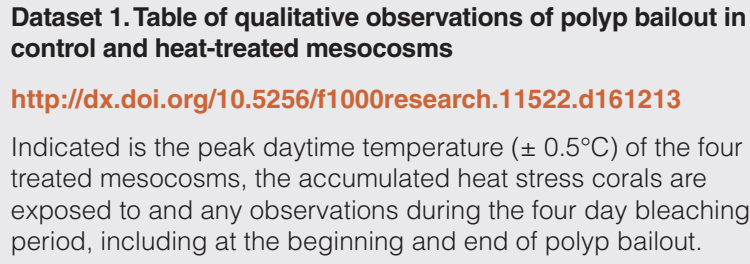

\section{Implications and future research}

In past observations of polyp bailout, corals have been subjected to extreme aquarium conditions such as high salinity (up to 54 parts per thousand; Shapiro et al., 2016), low pH (7.2; Kvitt et al., 2015) or little to no water replacement resulting in anoxic and low nutrient conditions (Serrano et al., 2017; Sin et al., 2012). This makes it difficult to apply these results to the context of natural systems and elucidate the possible role of this response during environmental stress. The present observation was in aquaria with near-natural conditions. The peak daily temperature of $34^{\circ} \mathrm{C}$ was sustained over several days, reflecting severe thermal stress. However, accumulated heat stress amounted to between two and three degree heating weeks (14-21 degree heating days). This is becoming widely reported during bleaching events on the Great Barrier Reef (Ainsworth et al., 2016; Hughes et al., 2017). Therefore, this observation suggests that polyp bailout can occur in natural reef environments, in response to currently observed temperature increases. For coral species that utilise this response, the present record has implications for coral recruitment and recovery on local scales, and also suggests that these processes can occur independent of sexual reproduction and the impact of thermal stress on reproductive potential.

Detached polyps appear to be viable, able to settle near the parent colony and capable of being dispersed short distances in a reef environment. Sammarco (1982) previously described low $(<5 \%)$ settlement and survival rates of detached polyps on settlement tiles contained in jars but survival of individual polyps within a simulated or natural reef environment has yet to be investigated, particularly how it is affected by reef degradation. If polyps were to 'escape' into cooler conditions with higher food availability, it may boost their survival and settlement success rates beyond the 5\% observed by Sammarco. In the current study, we noted that each parent colony detached a large population of individual polyps ( $>50$ per fragment), showing that even survival of $5 \%$ has the potential to allow from some immediate re-seeding of the local reef habitat. Furthermore, an obvious source of nearby refugia are neighbouring reef slope and mesophotic reef environments (Bridge et al., 2013; Smith et al., 2014), down to which these negatively buoyant polyps may slowly sink. However, light attenuation may limit viable settlement depths as individual polyps would need to rapidly acclimate to lower light conditions in order to settle and successfully begin asexual division.

Clearly, extensive future research is needed to explore the survival of individual polyps in both simulated refugia and within the reef habitat following thermal stress events. This will lead to greater understanding of the ecology and wider implications of this stress response and its potential role in coral recruitment and reef recovery following bleaching events. We additionally lack in situ observations of this phenomenon. Time-intensive ecological surveying during a predicted bleaching event is needed to reveal whether this is a widespread response to thermal stress. Subsequent use of mass mark and recapture of coral polyps, tagged with stable heavy isotopes, would then allow the tracking of the fate of coral polyps following bailout. Despite being a wellestablished response to stress, little research has focused on how polyp bailout may influence the survival and recovery of local coral populations.

\section{Data availability}

Dataset 1. Table of qualitative observations of polyp bailout in control and heat-treated mesocosms. Indicated is the peak daytime temperature $\left( \pm 0.5^{\circ} \mathrm{C}\right)$ of the four treated mesocosms, the accumulated heat stress corals are exposed to and any observations during the four day bleaching period, including at the beginning and end of polyp bailout.

DOI, 10.5256/f1000research.11522.d161213 (Fordyce et al., 2017)

Author contributions

TDA made the initial observation of polyp bailout. EFC photographed bailout for Figure 1. AJF photographed polyps for Figure 2 and prepared the first draft of the manuscript. All authors contributed to subsequent revisions of the manuscript and have agreed to the final content.

\section{Competing interests}

No competing interests were disclosed.

\section{Grant information}

The author(s) declared that no grants were involved in supporting this work.

\section{Acknowledgements}

The authors thank the Heron Island Scientific Services for their support during field work. 


\section{Supplementary Material}

Supplementary Material 1. Comparative photographs of control and bleached fragments to show bleaching. Photographs were taken using an Olympus Stylus Tough TG-4 camera. A) Photograph of control fragment taken on 31/01/17; B) Photograph of bleached fragment, with visibly withdrawn individual polyps still attached to the skeleton, taken on 30/01/17.

Click here to access the data.

Ainsworth TD, Heron SF, Ortiz JC, et al:: Climate change disables coral bleaching protection on the Great Barrier Reef. Science. 2016; 352(6283): 338-342. PubMed Abstract | Publisher Full Text

Bridge TC, Hoey AS, Campbell SJ, et al:: Depth-dependent mortality of reef corals following a severe bleaching event: implications for thermal refuges and population recovery [version 3; referees: 2 approved, 1 approved with reservations]. F1000Res. 2013; 2: 187

PubMed Abstract | Publisher Full Text | Free Full Text

Fordyce AJ, Camp EF, Ainsworth TD: Dataset 1 in: Polyp bailout in Pocillopora damicornis following thermal stress. F1000Research. 2017. Data Source

Goreau TH, Goreau NI: The physiology of skeleton formation in corals. II. Calcium deposition by hermatypic corals under various conditions in the reef. Biol Bull. 1959; 117(2): 239-250.

Publisher Full Text

Hughes TP, Kerry JT, Álvarez-Noriega M, et al:: Global warming and recurrent mass bleaching of corals. Nature. 2017; 543(7645): 373-377.

PubMed Abstract | Publisher Full Text

Kvitt $\mathrm{H}$, Kramarsky-Winter $\mathrm{E}$, Maor-Landaw $\mathrm{K}$, et al.: Breakdown of coral colonial form under reduced $\mathrm{pH}$ conditions is initiated in polyps and mediated through apoptosis. Proc Natl Acad Sci U S A. 2015; 112(7): 2082-2086. PubMed Abstract | Publisher Full Text | Free Full Text

Richmond RH: Reversible metamorphosis in coral planulae larvae. Mar Ecol
Prog Ser. 1985; 22: 181-185.

Publisher Full Text

Sammarco PW: Polyp bail-out: an escape response to environmental stress and a new means of reproduction in corals. Mar Ecol Prog Ser. 1982; 10: 57-65. Publisher Full Text

Serrano E, Coma R, Inostroza K, et al.: Polyp bail-out by the coral Astroides calycularis (Scleractinia, Dendrophylliidae). Mar Biodiv. Published online. 2017; 1-5.

Publisher Full Text

Shapiro $\mathrm{OH}, \mathrm{Kramarsky}$-Winter E, Gavish AR, et al:: A coral-on-a-chip microfluidic platform enabling live-imaging microscopy of reef-building corals. Nat Commun. 2016; 7: 10860.

PubMed Abstract | Publisher Full Text | Free Full Text

Sin LC, Walford J, Goh BP: The effect of benthic macroalgae on coral settlement. Contrib Mar Sci. 2012; 2012: 89-93.

Publisher Full Text

Smith TB, Glynn PW, Maté JL, et al:: A depth refugium from catastrophic coral bleaching prevents regional extinction. Ecology. 2014; 95(6): 1663-1673.

PubMed Abstract | Publisher Full Text

van Hooidonk R, Maynard J, Tamelander J, et al.: Local-scale projections of coral reef futures and implications of the Paris Agreement. Sci Rep. 2016; 6: 39666.

PubMed Abstract | Publisher Full Text | Free Full Text 


\section{Open Peer Review}

\section{Current Peer Review Status:}

\section{Version 1}

Reviewer Report 24 July 2017

https://doi.org/10.5256/f1000research.12446.r22841

(C) 2017 Tchernov D et al. This is an open access peer review report distributed under the terms of the Creative Commons Attribution License, which permits unrestricted use, distribution, and reproduction in any medium, provided the original work is properly cited.

\section{Dan Tchernov}

School of Marine Sciences, University of Haifa, Haifa, Israel

\section{Hagit Kvitt}

School of Marine Sciences, University of Haifa, Haifa, Israel

General remarks:

1. In the Abstract the authors claim: "However, polyp bailout has not previously been described in association with thermal stress and the coral bleaching response..."

a. This is completely inaccurate-polyp bailout or expulsion in response to thermal stress has been reported in 2007 by Kruzic $P$.

b. Moreover, the claim that bleaching is also involved: "in association with thermal stress and the coral bleaching response" is misleading - there is not a single experimental proof or measurement of bleaching in the current report, merely some remarks on "Paling observed in coral tissue" and "All corals fully bleached" (Dataset 1.). Moreover, the polyps are clearly detaching with the zooxanthellae, (Figure 2: "Small brown dots in the polyp tissue are endosymbiotic zooxanthellae"). So where is the bleaching? In the coenosarc? If so experimental evidence should be provided. Or the sentence: "..the coral bleaching response" should have been omitted.

2. In the Results, the use of the term "heating days" is unclear, and should have been explained ("At this time, peak daytime temperature was $33^{\circ} \mathrm{C}$, which is the equivalent of 13 degree heating days, a measure of accumulated heat stress used in the prediction of mass bleaching events ").

3. Figure 2 is unclear, especially the presumed "coiled filaments are adhesive mesenterial filaments, presumed to aid in rapid settlement". I would expect, under current technologies available, for a better image to convince that indeed these are "adhesive mesenterial filaments". 
The literature is not correctly cited.

1. In the Abstract, the paper by Goreau \& Goreau (1959) does not clearly describe polyp bailout or expulsion. It deals with calcification all over, and it mentions merely in the Discussion, as unpublished results, that polyps can detach. This citation should have been be omitted from the Abstract and put elsewhere.

2. The paper of Kramarsky-Winter et al. 1997 on polyp expulsion is not cited.

3. The paper of Kruzic P. 2007 on polyp expulsion under thermal stress, which is the most relevant paper to this report, is not cited.

Is the work clearly and accurately presented and does it cite the current literature? No

Is the study design appropriate and is the work technically sound?

Yes

Are sufficient details of methods and analysis provided to allow replication by others? Yes

If applicable, is the statistical analysis and its interpretation appropriate? Not applicable

Are all the source data underlying the results available to ensure full reproducibility? Yes

Are the conclusions drawn adequately supported by the results?

No

Competing Interests: No competing interests were disclosed.

We confirm that we have read this submission and believe that we have an appropriate level of expertise to confirm that it is of an acceptable scientific standard, however we have significant reservations, as outlined above.

Reviewer Report 19 June 2017

https://doi.org/10.5256/f1000research.12446.r23072

(C) 2017 Agostini S. This is an open access peer review report distributed under the terms of the Creative Commons Attribution License, which permits unrestricted use, distribution, and reproduction in any medium, provided the original work is properly cited.

Sylvain Agostini 
Shimoda Marine Research Center, University of Tsukuba, Shizuoka, Japan

This paper reports on the qualitative of polyp bailout for the coral species Pocillopora damicornis under heat stress in mesocosms.

The study remains qualitative and the authors are clear on this point.

The only remark I would have is in the discussion. The sentence "Detached polyps appear to be viable, able to settle near the parent colony and capable of being dispersed short distances in a reef environment." sounds like that resettlement of the bailed polyp were observed. However it was not observed and remain a speculation. I would suggest to rephrase it to something like that: "While resettlement of the bailed out polyps could not be observed, the polyps appear to be viable, and could be able to settle near the parent colony and to be dispersed accross short distances in a reef environment."

Is the work clearly and accurately presented and does it cite the current literature? Yes

Is the study design appropriate and is the work technically sound?

Yes

Are sufficient details of methods and analysis provided to allow replication by others? Yes

If applicable, is the statistical analysis and its interpretation appropriate? Yes

Are all the source data underlying the results available to ensure full reproducibility? Yes

Are the conclusions drawn adequately supported by the results? Partly

Competing Interests: No competing interests were disclosed.

I confirm that I have read this submission and believe that I have an appropriate level of expertise to confirm that it is of an acceptable scientific standard.

\section{Comments on this article}

\section{Version 1}

Author Response 05 Jun 2017

Alexander Fordyce, James Cook University, Queensland, Australia 
Dear Dr Shapiro,

Thank you for highlighting this, very relevant in addressing the questions highlighted in this research note. We'll be sure to update the manuscript to include this information which will undoubtedly improve its quality.

Thank you again,

Best wishes,

Alexander Fordyce

Competing Interests: No competing interests were disclosed.

Reader Comment 03 Jun 2017

Orr Shapiro, Volcani institute, ARO, Israel

Please note that in the experiments reported in our "Coral on a chip" paper (Shapiro et al 2016) settling rates were often above $50 \%$, much higher than the $5 \%$ reported by Sammarco. The low settling rates in that work may be due to poor incubation conditions, as he reports transferring bailed-out polyps to new jars, with new seawater but no flow. I would thus expect initial survival and settlement in the natural reef environment to be considerably higher than that reported by Sammarco.

Competing Interests: No competing interests were disclosed.

The benefits of publishing with F1000Research:

- Your article is published within days, with no editorial bias

- You can publish traditional articles, null/negative results, case reports, data notes and more

- The peer review process is transparent and collaborative

- Your article is indexed in PubMed after passing peer review

- Dedicated customer support at every stage

For pre-submission enquiries, contact research@f1000.com 